\title{
Environmental analysis and the planning process in a South African context
}

\author{
P.A. Miller \\ Graduate School of Business, University of Cape Town \\ N. Binedell \\ GEC Equipment (Pty) Ltd, Denver
}

\begin{abstract}
The authors of this paper examine the extent of the application of environmental analysis during the planning process in South African businesses. Overseas, and in the United States in particular, sophisticated techniques for analysing the environment are being developed, and these would appear to have a ready market in the South African environment. Should South African business tace relatively turbulent times in the near future, there will be a need for companies to develop effective means of analysing changing trends, and of integrating their findings into the strategic planning process. Two separate research surveys were conducted, one of 150 listed companies and a second of 15 major South African companies. While most journals and texts would see the environmental analysis as an integral part of the planning process, the majority of companies did not agree with this view.

S. Afr. J. Bus. Mgmt. 1982, 13: 113-117
\end{abstract}

Die skrywers van hierdie artikel ondersoek die mate waarin omgewingsontleding tydens die beplanningsproses in Suid. Afrikaanse ondernemings toegepas word. In die buiteland en veral in die Verenigde State, word verfynde tegnieke vir ontleding van die omgewing ontwikkel en daar behoort 'n goeie mark hievoor in die Suid.Afrikaanse omgewing te wees. Indien Suid-Afrikaanse ondernemings in die nabye toekoms relatief ontstuimige tye in die gesig sou staar, sal dit nodig wees dat maatskappye effektiewe maniere ontwikkel om die veranderende neigings te ontleed en om hulle bevindings met die strategiese beplanningsproses te integreer. Twee afsonderlike navorsingopnames is gedoen, een van 'n lys van 150 genoteerde maatskappye en 'n tweede van 15 groot Suid-Afrikaanse maatskappye. Alhoewel die meeste vaktydskrifte en handboeke omgewingsontleding as ' $n$ integrale deel van die beplanningsproses beskou, het die meeste maatskappye nie met hierdie mening saamgestem nie.

S.Afr. Tydskr. BedryfsI. 1982, 13: 113-117

\footnotetext{
P.A. Mink

Senior Lecturer, Graduate School of Business, Univer sity of Cape Town.

Rondebosch 7700, Republic of South Africa

N. Btedel

General Manager, GEC Equipment (Pty) Lid, 322 Main Reef Road, Denver

2094, Republic of South Africa

Received May 1982; accepted June 1982
}

\section{Introduction}

Whether the South African business environment is becoming relatively more turbulent when compared with its past or relative to other business environments is a matter for conjecture and individual opinion.

The development of techniques for systemized environmental analysis in the United States indicates that either management science is advancing in that systematic procedures are being developed, or that the environment itself is becoming increasingly complex and interactive, and therefore requires systematic analysis. Proponents of future research such as Kahn ${ }^{1}$ and Bell ${ }^{2}$ advocate the view that the environment is changing more rapidly than before, and is moving in fundamentally new directions.

The authors would suggest that as a rapidly developing economy, the complexity of the South African environment is increasing in a number of areas which impact on the conduct of business. More controversial perhaps is the view that for various reasons the South African macro-environment will undergo fundamental shifts, and will be pressured in various ways which will inevitably lead to new opportunities and shifts for the business community in general terms, and within particular industries.

Table 1 indicates the nature of possible sources of environmental turbulence in South Africa in the future.

Should these issues develop as pressure points in the environment, and the hypothesis that the South African business environment faces a relatively turbulent outlook be vindicated, then it is clear that there will be pressure on companies to develop effective means of analysing these shifts and trends in the environment in which they will operate. More importantly, managers will need to develop means of meaningfully integrating the outcome of environmental analysis into the strategic planning process.

\section{The need for environmental analysis}

The evolution of economic activity has led to the development of large organizations comprising a host of activities and individuals. This increased size has in turn led to increased complexity in terms of dependencies, relationships, purposes and courses of action. As a result, managers have had to learn to attend to those sectors of their environment which demand action. If they do not, they tend to lose their competitive advantage, missing opportunities and 
Table 1 Possible future sources of turbulence in the South African environment

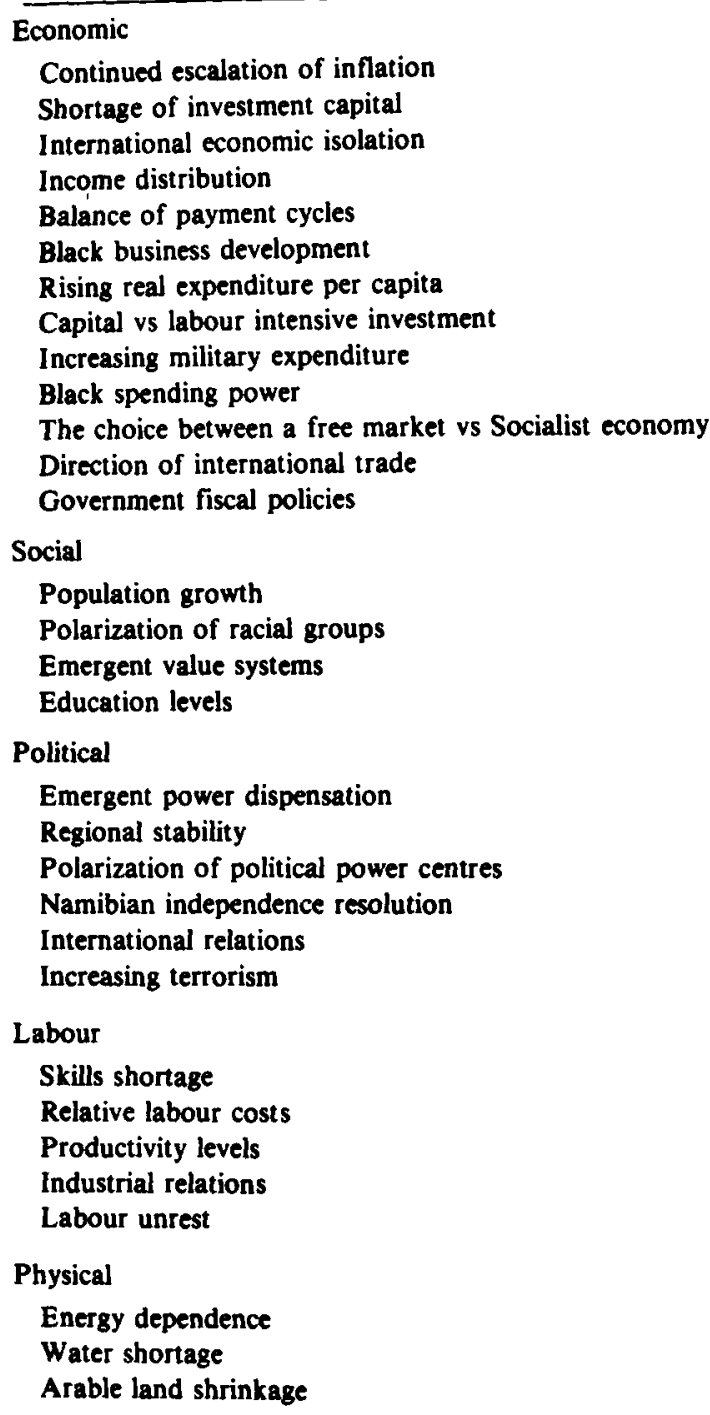

eventually increasing their companies' costs. In the long run the company's existence may even be threatened.

The key to the increased importance of managing a company in relation to its environment is rooted in the speed of change. Drucker has indicated that the current paradigms of the planning process will simply not work in turbulent times. 'Planning starts out, as a rule, with the trends of yesterday and projects them into the future using a different "mix" perhaps, but with very much the same elements and configuration. The most probable assumption in a period of turbulence is the unique event which changes with configuration - and unique events cannot by definition be planned.' 3

Our experience suggests that most companies are not structured or organized in order to deal with a rapidly changing environment. Rewards and incentives are structured around smooth growth in a simple, predictable environment, while the true environment appears to be complex, uncertain and problematic. However, developments in the areas of futures research and environmental scanning may indicate that management is starting to realize that there is a need to understand and deal with these issues through institutionalizing the flow of external information which is relevant to its strategies and prosperity.

\section{The state of the art}

Techniques for environmental analysis and futures research have received increasing attention in journals and manage. ment journais dealing with strategic planning and corporate strategy. Fahey and King ${ }^{4}$ in 1977 showed that only two out of 12 major corporations studied had established environmental analysis systems and that even those two com panies were scanning on a regular but not a continuous basis. 'Overall these results reveal a significant gap be tween the conventional assumptions concerning environmental scanning and its implementation in large corporations. Although the trend is toward greater sophistication, not enough evidence of demonstrated impact exists to warrant a conclusion that environmental scanning will become a regular element of corporate planning. '" Recently they examined the use of various environmental analysis techniques. 'Aware professionals' - members of the World Futures Society - were asked to rate the current usage and perceived utility of various methods on a scale of 0-7. Results are shown in Table 2.

Table 2 Perceived potential utility and actual usage of forecasting methods

\begin{tabular}{lll}
\hline Method & Utility & Usage \\
\hline Scenario writing & 6,1 & 4,2 \\
Simulation & 4 & 2 \\
Morphological analysis & 4,2 & 2,1 \\
PPBS & 2 & 2 \\
Game theory & 2 & 2 \\
Cross impact analysis & 3,9 & 2 \\
Input-output analysis & 4,8 & 2,9 \\
Field anamolyrelation & 2 & 2 \\
Other (including Delphi) & 6,1 & 5,1 \\
\hline
\end{tabular}

Source: Fahey, L. and King, R., Environmental scanning and forecasting in strategic planning. Long Range Planning, February 1981, p.35

Their general conclusions were that the average level of practice is low relative to the viewpoint expressed in journals and texts; the most sophisticated approach to scan. ning appears to be the establishment of a separate scan ning unit although there is no clear agreement of the ap propriateness of separate scanning units; and that en vironmental analysis is not regarded as sufficiently important to necessitate a major deployment of resources.

Thomas on the other hand concluded that 'the prevailing stereotype of environmental scanning as a marginal ivory tower exercise requires modification. In order to capture the essence of the scanning process, one has to move away from the conventional micro view of a single individual carrying out this function, to a macro one which is organic (if not fully organized yet) in character . . . (and as a result) systematic omni-directional scanning for corporate planning is on the threshold of rapid growth and development' ${ }^{\prime 6}$ (authors' words in parenthesis).

\section{Corporate sensitivity of the environment}

In order to determine whether listed South African companies showed increased sensitivity to the macro environment as suggested by Thomas and the extent of environment analysis within the formalized planning process, two 
separate research surveys were conducted: One, a mailed questionnaire sent to 150 listed companies and another, a series of focus interviews with 15 major South African companies.

Because the authors expected to encounter a great diversity of levels of sophistication ranging from ad hoc informal scanning by the chief executive to regular formal analysis by specialist functions, the limitations of a mailed questionnaire were acknowledged and it was accepted that a meaningful perspective could only be added through in-depth discussion with executives and planning managers.

\section{Objectives}

The research objectives were:

- To determine the extent of the use of environmental analysis in South African companies, this being seen as part of the overall planning process, and

- to establish how the environmental analysis is integrated into the planning process and eventually into the management culture of the company.

(Other objectives were included but fall outside the scope of this paper.)

The questionnaire was sent to 150 listed companies chosen on a systematic sampling basis, that is the total number of listed companies divided by the sample required $(450 / 150)$ meant that every fourth company was selected from the alphabetical index. This gave a total of 135 and a further 15 were randomly included. The use of an alphabetical index ensured that no bias by type of industry was possible. A total of 35 questionnaires were returned of which $31(20,67 \%)$ were usable. The salient findings of the survey were:

\section{Findings of questionnaire survey No formal planning department}

A total of $21(67,7 \%)$ of companies had no formal planning department or person assigned to a planning role. While the authors concluded that this did not necessarily indicate that companies without a specifically assigned planning task are poor planners, the planning task does require specialist skills, and insufficient resources or energy devoted to the planning function could lead to poor planning. The planning function in the majority of these companies $(61 \%)$ was carried out by the chief executive officer or the chief financial officer individually or together. Subsequently only one of these companies had its marketing personnel involved in the planning process.

\section{Planning focus}

Companies with a formal planning function utilized a mean planning time horizon of 4,4 years and those without had a mean of 3,9 years. Generally the focus of most formal planning was on the financial aspects of the firm, with the five most popular planning components as shown in Table 3.

\section{Environmental analysis}

Environmental anaiysis rated fairly poorly, with only 17 companies ( $55 \%$ of the survey) carrying out any type of environmental analysis. Of these, 10 were among those without a formal planning function. The time horizon was 3,05 years, considerably shorter than for projected capital
Table 3 The most popular planning components

\begin{tabular}{|c|c|c|c|}
\hline & Planning component & $\begin{array}{c}\% \% \\
\text { of companies }\end{array}$ & $\begin{array}{l}\text { Time horizon } \\
\text { mean value in years }\end{array}$ \\
\hline 1. & Projected cash flows & 90 & 3,32 \\
\hline 2. & $\begin{array}{l}\text { Projected income } \\
\text { statements }\end{array}$ & 90 & 3,59 \\
\hline 3. & $\begin{array}{l}\text { Projected capital } \\
\text { investments }\end{array}$ & 87 & 3,88 \\
\hline 4. & $\begin{array}{l}\text { Projected balance } \\
\text { sheets }\end{array}$ & 84 & 2,96 \\
\hline 5. & $\begin{array}{l}\text { Review of past } \\
\text { performance }\end{array}$ & 77 & 1,88 \\
\hline
\end{tabular}

investments. The authors surmised that in a dynamic environment, analysis time horizon may be necessarily short.

\section{Environmental sectors analysed}

The macro environment is depicted in terms of a diagram made up of six environmental sectors impacting on an industry and on individual companies (see Figure 1). Respondents were asked to what extent their companies analysed each environmental sector (see Table 4).

The economic environment is the most commonly analysed sector. Of the 31 companies that responded, 29 either analyse or analyse in detail the economic environment. Compared with the economic, physical, social and technological environments, the political and institutional/legal environments receive relatively little analytical attention. Clearly firms with formal planning functions have increased awareness of environmental analysis as a whole, and therefore were more likely to analyse each sector, whereas those firms not analysing a particular sector usually disregarded this sector because they felt it was not relevant to their particular industry.

Sources of information used for the purposes of the environmental analysis were varied but the most popular were (in descending order of popularity)

- Commercial bank reports

- Department of Statistics

- Bureau for Economic Research

- Trade journals

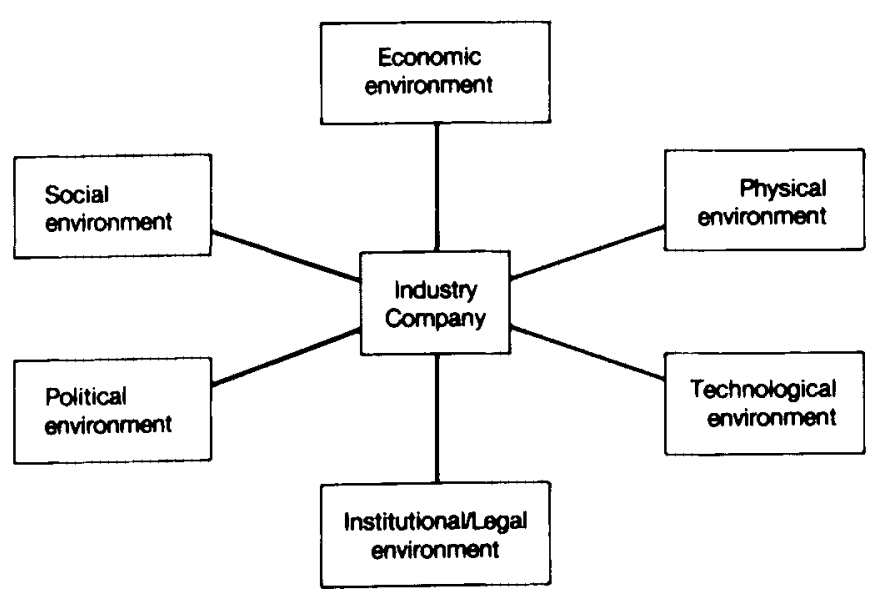

Figure 1 Six environmental sectors impacting on industry and companies 
Table 1 Possible future sources of turbulence in the South African environment

Economic
Continued escalation of inflation
Shortage of investment capital
International economic isolation
Income distribution
Balance of payment cycles
Black business development
Rising real expenditure per capita
Capital vs labour intensive investment
Increasing military expenditure
Black spending power
The choice between a free market vs Socialist economy
Direction of international trade
Government fiscal policies
Social
Population growth
Polarization of racial groups
Emergent value systems
Education levels
Political
Emergent power dispensation
Regional stability
Polarization of political power centres
Namibian independence resolution
International relations
Increasing terrorism
Labour
Skills shortage
Relative labour costs
Productivity levels
Industrial relations
Labour unrest
Energy dependence
Water shortage
Arable land shrinkage

eventually increasing their companies' costs. In the long run the company's existence may even be threatened.

The key to the increased importance of managing a company in relation to its environment is rooted in the speed of change. Drucker has indicated that the current paradigms of the planning process will simply not work in turbulent times. 'Planning starts out, as a rule, with the trends of yesterday and projects them into the future using a different "mix" perhaps, but with very much the same elements and configuration. The most probable assumption in a period of turbulence is the unique event which changes with configuration - and unique events cannot by definition be planned.' ${ }^{3}$

Our experience suggests that most companies are not structured or organized in order to deal with a rapidly changing environment. Rewards and incentives are structured around smooth growth in a simple, predictable environment, while the true environment appears to be complex, uncertain and problematic. However, developments in the areas of futures research and environmental scanning may indicate that management is starting to realize that there is a need to understand and deal with these issues through institutionalizing the flow of external information which is relevant to its strategies and prosperity.

\section{The state of the art}

Techniques for environmental analysis and futures research have received increasing attention in journals and management journals dealing with strategic planning and corporate strategy. Fahey and $\mathrm{King}^{4}$ in 1977 showed that only two out of 12 major corporations studied had established environmental analysis systems and that even those two com. panies were scanning on a regular but not a continuous basis. 'Overall these results reveal a significant gap between the conventional assumptions concerning environmental scanning and its implementation in large corporations. Although the trend is toward greater sophistication, not enough evidence of demonstrated impact exists to warrant a conclusion that environmental scanning will become a regular element of corporate planning.'s Recently they examined the use of various environmental analysis techniques. 'Aware professionals' - members of the World Futures Society - were asked to rate the current usage and perceived utility of various methods on a scale of $0-7$. Results are shown in Table 2.

Table 2 Perceived potential utility and actual usage of forecasting methods

\begin{tabular}{lll}
\hline Method & Utility & Usage \\
\hline Scenario writing & 6,1 & 4,2 \\
Simulation & 4 & 2 \\
Morphological analysis & 4,2 & 2,1 \\
PPBS & 2 & 2 \\
Game theory & 2 & 2 \\
Cross impact analysis & 3,9 & 2 \\
Input-output analysis & 4,8 & 2,9 \\
Field anamolyrelation & 2 & 2 \\
Other (including Delphi) & 6,1 & 5,1 \\
\hline
\end{tabular}

Source: Fahey, L. and King, R., Environmental scanning and forecasting in strategic planning. Long Range Planning, February 1981, p.35

Their general conclusions were that the average level of practice is low relative to the viewpoint expressed in journals and texts; the most sophisticated approach to scanning appears to be the establishment of a separate scanning unit although there is no clear agreement of the appropriateness of separate scanning units; and that environmental analysis is not regarded as sufficiently important to necessitate a major deployment of resources.

Thomas on the other hand concluded that 'the prevailing stereotype of environmental scanning as a marginal ivory tower exercise requires modification. In order to capture the essence of the scanning process, one has to move away from the conventional micro view of a single individual carrying out this function, to a macro one which is organic (if not fully organized yet) in character . . . (and as a result) systematic omni-directional scanning for corporate planning is on the threshold of rapid growth and development, ${ }^{6}$ (authors' words in parenthesis).

\section{Corporate sensitivity of the environment}

In order to determine whether listed South African companies showed increased sensitivity to the macro environment as suggested by Thomas and the extent of environment analysis within the formalized planning process, two 
separate research surveys were conducted: One, a mailed questionnaire sent to 150 listed companies and another, a series of focus interviews with 15 major South African companies.

Because the authors expected to encounter a great diversity of levels of sophistication ranging from ad hoc informal scanning by the chief executive to regular formal analysis by specialist functions, the limitations of a mailed questionnaire were acknowledged and it was accepted that a meaningful perspective could only be added through in-depth discussion with executives and planning managers.

\section{Objectives}

The research objectives were:

- To determine the extent of the use of environmental analysis in South African companies, this being seen as part of the overall planning process, and

- to establish how the environmental analysis is integrated into the planning process and eventually into the management culture of the company.

(Other objectives were included but fall outside the scope of this paper.)

The questionnaire was sent to 150 listed companies chosen on a systematic sampling basis, that is the total number of listed companies divided by the sample required $(450 / 150)$ meant that every fourth company was selected from the alphabetical index. This gave a total of 135 and a further 15 were randomly included. The use of an alphabetical index ensured that no bias by type of industry was possible. A total of 35 questionnaires were returned of which $31(20,67 \%)$ were usable. The salient findings of the survey were:

\section{Findings of questionnaire survey No formal planning department}

A total of $21(67,7 \%)$ of companies had no formal planning department or person assigned to a planning role. While the authors concluded that this did not necessarily indicate that companies without a specifically assigned planning task are poor planners, the planning task does require specialist skills, and insufficient resources or energy devoted to the planning function could lead to poor planning. The planning function in the majority of these companies $(61 \%)$ was carried out by the chief executive officer or the chief financial officer individually or together. Subsequently only one of these companies had its marketing personnel involved in the planning process.

\section{Planning focus}

Companies with a formal planning function utilized a mean planning time horizon of 4,4 years and those without had a mean of 3,9 years. Generally the focus of most formal planning was on the financial aspects of the firm, with the five most popular planning components as shown in Table 3.

\section{Environmental analysis}

Environmental analysis rated fairly poorly, with only 17 companies (55\% of the survey) carrying out any type of environmental analysis. Of these, 10 were among those without a formal planning function. The time horizon was 3,05 years, considerably shorter than for projected capital
Table 3 The most popular planning components

\begin{tabular}{|c|c|c|c|}
\hline & Planning component & $\begin{array}{c}\% \\
\text { of companies }\end{array}$ & $\begin{array}{l}\text { Time horizon } \\
\text { mean value in years }\end{array}$ \\
\hline 1. & Projected cash flows & 90 & 3,32 \\
\hline 2. & $\begin{array}{l}\text { Projected income } \\
\text { statements }\end{array}$ & 90 & 3,59 \\
\hline 3. & $\begin{array}{l}\text { Projected capital } \\
\text { investments }\end{array}$ & 87 & 3,88 \\
\hline 4. & $\begin{array}{l}\text { Projected balance } \\
\text { sheets }\end{array}$ & 84 & 2,96 \\
\hline 5. & $\begin{array}{l}\text { Review of past } \\
\text { performance }\end{array}$ & 77 & 1,88 \\
\hline
\end{tabular}

investments. The authors surmised that in a dynamic environment, analysis time horizon may be necessarily short.

\section{Environmental sectors analysed}

The macro environment is depicted in terms of a diagram made up of six environmental sectors impacting on an industry and on individual companies (see Figure 1). Respondents were asked to what extent their companies analysed each environmental sector (see Table 4).

The economic environment is the most commonly analysed sector. Of the 31 companies that responded, 29 either analyse or analyse in detail the economic environment. Compared with the economic, physical, social and technological environments, the political and institutional/legal environments receive relatively little analytical attention. Clearly firms with formal planning functions have increased awareness of environmental analysis as a whole, and therefore were more likely to analyse each sector, whereas those firms not analysing a particular sector usually disregarded this sector because they felt it was not relevant to their particular industry.

Sources of information used for the purposes of the environmental analysis were varied but the most popular were (in descending order of popularity)

- Commercial bank reports

- Department of Statistics

- Bureau for Economic Research

- Trade journals

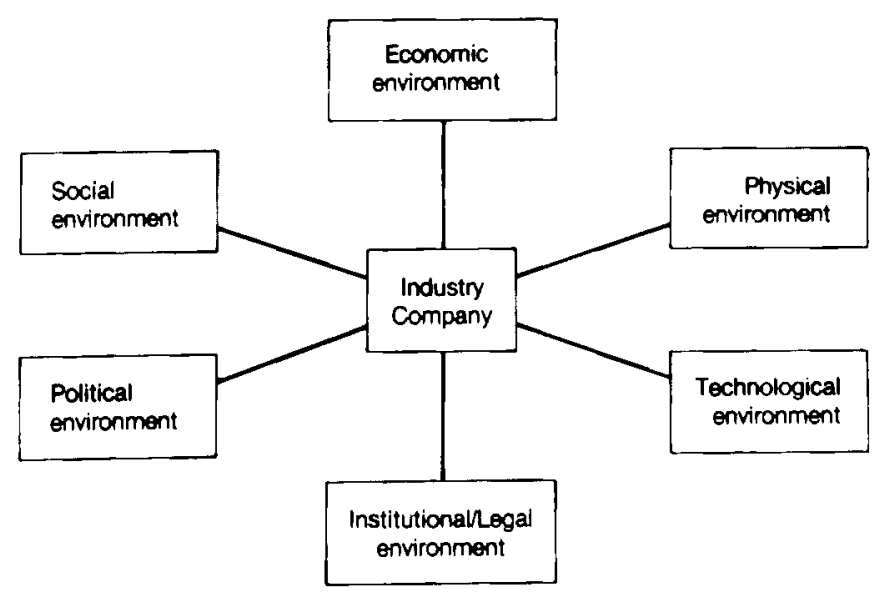

Figure 1 Six environmental sectors impacting on industry and companies 
Table 4 Analysis of six environmental sectors

\begin{tabular}{|c|c|c|c|c|c|c|c|c|c|}
\hline \multirow[b]{3}{*}{$\begin{array}{l}\text { Environmental } \\
\text { sector }\end{array}$} & \multicolumn{3}{|c|}{ Analysed in detail } & \multicolumn{3}{|c|}{ Analysed } & \multicolumn{3}{|c|}{ Not analysed } \\
\hline & \multicolumn{3}{|c|}{ Number of respondents } & \multicolumn{3}{|c|}{ Number of respondents } & \multicolumn{3}{|c|}{ Number of respondents } \\
\hline & $\begin{array}{l}\text { Companies } \\
\text { with } \\
\text { planning } \\
\text { function }\end{array}$ & $\begin{array}{l}\text { Companies } \\
\text { without } \\
\text { planning } \\
\text { function }\end{array}$ & $\begin{array}{l}\% \text { of } \\
\text { total }\end{array}$ & $\begin{array}{c}\text { Companies } \\
\text { with } \\
\text { planning } \\
\text { function }\end{array}$ & $\begin{array}{l}\text { Companies } \\
\text { without } \\
\text { planning } \\
\text { function }\end{array}$ & $\begin{array}{l}\% \text { of } \\
\text { total }\end{array}$ & $\begin{array}{c}\text { Companies } \\
\text { with } \\
\text { planning } \\
\text { function }\end{array}$ & $\begin{array}{c}\text { Companies } \\
\text { without } \\
\text { planning } \\
\text { function }\end{array}$ & $\begin{array}{l}\% \text { of } \\
\text { total }\end{array}$ \\
\hline Economic & 3 & 6 & 29 & 7 & 13 & 65 & 0 & 2 & 6 \\
\hline Physical & 2 & 5 & 23 & 7 & 9 & 52 & 1 & 7 & 26 \\
\hline Technological & 4 & 4 & 26 & 6 & 11 & 55 & 0 & 6 & 19 \\
\hline Institutional/legal & 0 & 1 & 3 & 7 & 9 & 52 & 1 & 11 & 39 \\
\hline Political & 0 & 1 & 3 & 8 & 13 & 68 & 2 & 7 & 29 \\
\hline Social & 1 & 2 & 10 & 7 & 15 & 71 & 2 & 4 & 19 \\
\hline
\end{tabular}

\section{Time horizons}

It was clear from the response that most companies do undertake formal planning even though no specialists may have been appointed to that function. These formal plans are still being formulated in the mystical five year time frame which might indicate the limitations of the unsophisticated nature of the environmental analysis. (Only one firm indicated any level of sophistication, this being an in-house econometric model.)

If companies were to make better use of those available sources of information that cast a broader net with longer time horizons, their analyses and planning would be far more effective.

\section{Findings on 15 companies interviewed}

As already stated, it was felt that the limited nature of a questionnaire would narrow the search, so a further 15 companies were interviewed. It was apparent that the companies selected were not representative of the earlier sample of quoted companies, but rather represented some of the more advanced companies in terms of corporate planning. The companies interviewed are shown by business sector in Table 5.

Table 5 Companies interviewed, by business sector

\begin{tabular}{lc}
\hline Business sector & Number of companies \\
\hline Industrial/Conglomerate & 4 \\
Oil/Energy & 4 \\
Service & 4 \\
Construction & 1 \\
Retail & 1 \\
Motor & 1 \\
\hline
\end{tabular}

It was found that a significant proportion of these companies (nine) practise what we termed low-level environmental analysis. This usually involved an annual environmental analysis as a prelude to the planning process. As with the earlier sample, the environmental analysis revolves around the economic and industrial environments including the parameters of the demand function and likely competitive responses. Usually a single view of the future environment is developed and used as a framework for the plan. Senior executives, subsidiary management and divisional managers do not get involved until presented with the final report on the departments' or individual's findings.

\section{More advanced environmental analysis}

Six companies practised a more advanced level of environmental analysis. First, line managers are involved to a greater degree in the environmental analysis. Second, senior executives are involved on an on-going basis as the environmental analysis is seen as a central aspect of the planning process. This seems to increase the sensitivity of these executives to the issues and trends developing in the environment, and is likely to develop an opportunistic future-oriented outlook.

As a general observation, the interviews demonstrated that the level of environmental analysis is related to the sophistication of the planning process. No companies interviewed presented evidence of an advanced environmental analysis procedure after showing that their planning process was rough and ready. A common comment from the planners interviewed was that the level of the environmental analysis should be related to the level of the planning process if it is to gain the interest and participation of line managers and strategic decision-makers. If the correct weighting is not maintained, the decision-maker is likely to reject the environmental analysis as being beyond the scope of his perception, business function or context.

\section{Integration of analysis}

Integration of the environmental analysis takes place at two levels: first in the minds of the strategic decisionmakers as part of their knowledge and cognitive processes when developing plans and strategies; second, as a written element of the planning document. The most important aspect is the integration of information and implications for the business which flow from the environmental analysis as understood and used by the decision-maker. Some corporate planners find themselves frustrated by the scant attention paid to the environmental analysis and its application to the development of strategy. It is clear that 
producing documents at considerable cost, which are then ignored, is a fatuous exercise. One of the companies in particular stood out because they had a relatively undeveloped environmental analysis process, but through direct and meaningful access to the chief executive this process had a major impact on strategy. This contrasted with those companies which had developed sophisticated systems that did not directly impact on the strategy-making process.

\section{Conclusion}

While most of the journals and texts would see the environmental analysis as an integral part of the planning process, the majority of companies surveyed carried out either low-level or limited environmental analyses, with few producing anything like the comprehensively researched reports visualized by most authors. Those that do produce such reports often have difficulty in integrating the findings on the annual planning process. On the other hand, companies with low level environmental analytical procedures seemed to find it easier to integrate environmental analysis with the planning process. The authors could only conclude that management in many South African firms at present do not see the need for full-scale environmental analysis as being a high priority item.

Based on the authors' exposure to the managers conducting corporate planning and exposure to the techniques and procedures used in corporate planning, it is clear that a considerable degree of concern exists about the impact of environmental dynamics on corporate strategy. The problems seem to be, firstly, to develop manageable procedures and, secondly, to integrate these into the mental mind maps of both the planners and line management. A tendency exists for line managers and planners to shrink back and avoid the more unpleasant aspects and the thornier problems uncovered through environmental analysis. This is possibly owing to the controversial nature of these issues and to the difficulties in terms of translating their impact on the corporate strategy into meaningful and acceptable terms.

In conclusion, the authors believe that the macro environment is likely to impose numerous strategic issues that business will have to consider in the medium- to long-term future of the South African economy. It is imperative that individual businesses and the business community as a whole effectively deal with these issues.

\section{Reterences}

1. Kahn, H. \& Weiver, A.J. The Year 2000. London: Macmillan, 1967.

2. Bell, D. The Coming of Post-Industrial Society. New York: Basic Books, 1973.

3. Drucker, P. Managing in Turbulent Times. London: Pan Books, 1981, p.9.

4. Fahey, L. \& King, R. Environmental scanning for corporate planning, Bus. Horizons, August 1977, Vol.20, No.4, p.71.

5. Thomas, $P$. Environmental scanning - The state of the art. Long Range Planning, February 1980, Vol.13, p.24. 